ECCOMAS

Proceedia
COMPDYN 2021

$8^{\text {th }}$ ECCOMAS Thematic Conference on Computational Methods in Structural Dynamics and Earthquake Engineering

M. Papadrakakis, M. Fragiadakis (eds.)

\title{
FRAGILITY CURVES DEFINITION OF EXISTING REINFORCED CONCRETE BUILDINGS DESIGNED FOR GRAVITY LOADS
}

\author{
A. Basaglia ${ }^{1}$, M. Terrenzi ${ }^{1}$ and E. Spacone ${ }^{1}$ \\ ${ }^{1}$ University "G. d'Annunzio" of Chieti-Pescara \\ Department of Engineering and Geology \\ Viale Pindaro 42, 65127 Pescara, Italy \\ e-mail: \{alberto.basaglia, marco.terrenzi, enrico.spacone\}@unich.it
}

\begin{abstract}
Urban areas with a significant number of buildings designed without earthquake resistant concepts may undergo high losses following major earthquakes. However, an adequate design is the direct result of a comprehensive knowledge of the seismic hazard. In Italy, for example, the seismic zonation was completed in recent years, thus a significant number of buildings lack adequate lateral capacity. For this reason, preventive assessment of their vulnerability and expected damage is crucial.

This paper presents the vulnerability assessment of two reinforced concrete buildings designed for gravity loads and representative of the Pescara Province in the Abruzzi Region (Central Italy). Geometrical and structural characteristics of the buildings are initially derived from an existing database based on structured interviews with local technicians. The two buildings are then modeled using a simulated design approach following two different buildings codes. Nonlinear dynamic analyses are carried out in order to derive a suite of fragility curves for different damage states. These curves may be used to predict the expected damage following earthquakes of increasing intensities and plan mitigation strategies.
\end{abstract}

Keywords: Seismic Risk, Vulnerability Assessment, Reinforced Concrete, Nonlinear Dynamic Analyses, Fragility Curves. 


\section{INTRODUCTION}

The European Union is actively trying to enhance the understanding of disaster risk by laying out a shared approach for loss assessments [1]. Italy committed to this effort by developing a National Risk Assessment (NRA) [2] which considered all potential disaster risks. Among potential risks, seismic risk induces the second highest loss of lives, especially in the Euro-Mediterranean Region.

A commonly agreed definition of seismic risk is the combination of hazard $(\mathrm{H})$, vulnerability $(\mathrm{H})$ and exposure $(\mathrm{E})[3]$, see Eq. 1:

$$
R=H \cdot V \cdot E
$$

Hazard relates to the probability of occurrence of an earthquake of a specified intensity in a defined period of time. Vulnerability relates to the potential damage undergone by the asset under assessment (e.g., a building) in the occurrence of the earthquake. Exposure relates to the potential losses (e.g., economic and social) caused by the building's damage.

Among the three aspects of Eq. 1, the vulnerability definition has proven to be the most challenging task, as it requires not only an extensive knowledge of all buildings under assessment, but also a detailed evaluation of their seismic response. The complexity of the task is further increased when dealing with large scale assessments. For these reasons, the concept of "minimal fragility portfolio" has been recently developed [4-6], which focuses on defining a reasonable number of buildings typologies that are representative of the whole built environment. By focusing on the derivation of fragility curves (which relates the probability of exceeding pre-defined damage states for increasing intensities [7]) only for these typologies, the time needed to perform large scale assessments is significantly reduced while keeping a sufficient level of accuracy.

In this paper, an existing database for Italian residential buildings is used to define two reinforced concrete $(\mathrm{RC})$ building typologies that are representative of the Pescara province, Central Italy. These buildings have been modeled using a simulated design approach [8] in order to perform non-linear dynamic analyses (NLDAs). Outputs of these analyses have been used to derive a suite of fragility curves for defined damage states.

\section{CASE STUDY DEFINITION}

The Abruzzo Region, Central Italy, is among the areas with the highest seismic risk in Italy, as showed by the extensive losses in the aftermath of the L'Aquila 2009 [9] and Central Italy 2016-2017 [10] earthquakes.
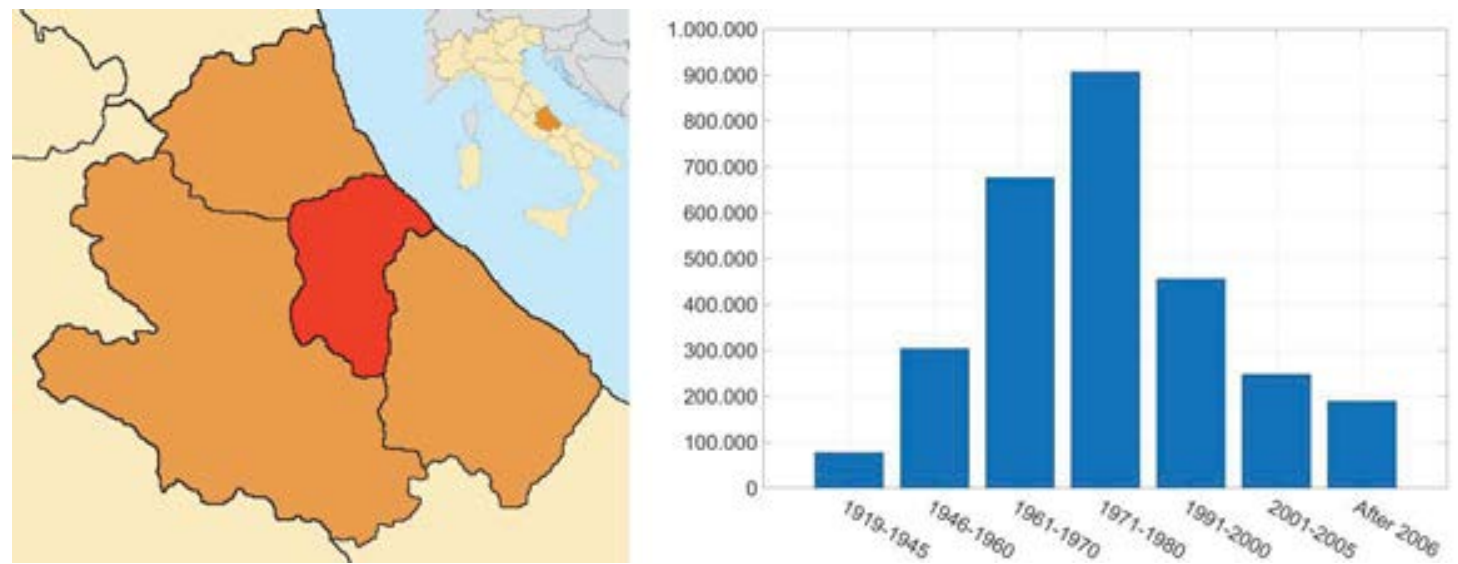

Figure 1. (left) Map of Italy with Abruzzo Region and Province of Pescara highlighted and (right) number of RC buildings in Italy per different construction periods. 
In the Abruzzo Region, the Province of Pescara spreads from the coast to the inner mountain areas, see Figure 1a, with the highest population density in the former. The coastal area has been fully included in the seismic zonation in 2003 [11] while the majority of RC buildings in Italy has been built between 1961 and 1980 (source: Census data [12]). For this reason, RC buildings in Pescara were designed considering only gravity loads (GLD) thus making them prone to damage even in the occurrence of earthquakes with moderate intensity.

To collect information on RC buildings in the Pescara Province, the database provided by the CARTIS project [13] has been used. The CARTIS project has been collecting data on the geometrical and structural features of residential buildings in Italy since 2014. The data collection is performed by filling a structured form through interviews with local technicians. The experience and knowledge of the technician ensure that collected data are accurate.

CARTIS data are freely accessible through the pgAdmin platform (https://www.pgadmin.org/). For RC buildings, the parameters provided in Table 1 are available.

\begin{tabular}{l}
\hline Parameter \\
\hline Main resisting system \\
Number of stories \\
Construction period \\
Seismic joints \\
Unidirectional frames \\
Ground floor infill walls \\
Soft story upper floors \\
Presence of SAP slabs (or similar) \\
Regularity in plan \\
Regularity in elevation \\
Roof material \\
Roof spread \\
Structural strengthening \\
\hline
\end{tabular}

Table 1. Parameters available in the CARTIS database for RC buildings (in bold, those used for the relevant typologies definition).

Parameters of Table 1 in bold have been used to determine the most relevant typologies for the Pescara Province, whose characteristics are listed in Table 2.

\begin{tabular}{cccccccc}
\hline ID & $\begin{array}{c}\text { Main resisting } \\
\text { system }\end{array}$ & $\begin{array}{c}\text { No. of } \\
\text { Stories }\end{array}$ & $\begin{array}{c}\text { Construction } \\
\text { Period }\end{array}$ & $\begin{array}{c}\text { Design } \\
\text { Type }\end{array}$ & $\begin{array}{c}\text { Unidirectional } \\
\text { frame }\end{array}$ & $\begin{array}{c}\text { Ground floor } \\
\text { infill walls }\end{array}$ & $\begin{array}{c}\text { Regularity } \\
\text { in plan }\end{array}$ \\
\hline A $\begin{array}{c}\text { Frames with exposed } \\
\text { beams and non- } \\
\text { sturdy infill walls }\end{array}$ & $4-6$ & $1946-1960$ & GLD & Yes & $\begin{array}{c}\text { Regular } \\
\text { configuration }\end{array}$ & Regular \\
B $\begin{array}{c}\text { Frames with exposed } \\
\text { beams and non- } \\
\text { sturdy infill walls }\end{array}$ & $4-6$ & $1971-1980$ & GLD & Yes & $\begin{array}{c}\text { Regular } \\
\text { configuration }\end{array}$ & Regular \\
\hline
\end{tabular}

Table 2. Characteristics of relevant RC building typologies for the Pescara Province based on CARTIS data. 


\section{MODELING APPROACH}

\subsection{Design codes, geometry, loads and material properties definition}

To model the buildings listed in Table 2, a simulated design approach [8] has been used. Following this approach, the design loads, material properties, and construction details have been determined based on the codes in use at the time of the construction. More specifically, R.D.L. 1939 [14] and D.M. '72 [15] have been used for RC typologies A and B, respectively. In addition, as both typologies were designed for gravity loads and the only load combination used is the sum of dead $(G)$ and live $(Q)$ loads. This design type does not change for increasing number of stories, the focus has been put on the six-story buildings. The 4 and 5-story buildings have been subsequently derived by taking the upper 4 and 5 stories, respectively.

At first, the buildings' layout is assumed, as no geometrical information was provided by the CARTIS data. The assumed plan layout is derived by existing studies that analyzed buildings of the same period [14,15] and is shown in Figure 2. In the inner frames, beams are present only in the $\mathrm{X}$ direction, thus making the $\mathrm{Y}$ direction less resistant to lateral forces. Each story is $3 \mathrm{~m}$ height, for a total height of $18 \mathrm{~m}$.

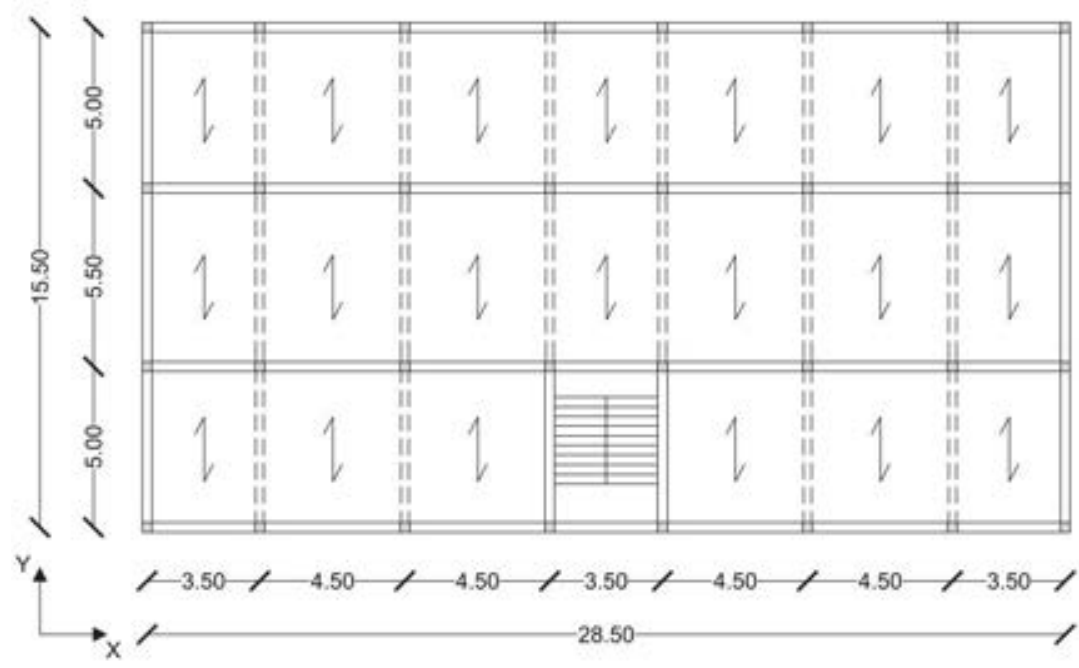

Figure 2. Assumed plan layout (dotted, the bond-beams in the Y direction).

As for the design loads, the R.D.L. 1939 does not provide any value, therefore they had to be assumed based on the experience. On the other hand, the D.M. ' 72 refers to another code for the definition of $G$ and $Q$ [16]. Design loads for Building A and B are assumed equal and are listed in Table 3, divided between story levels 1-5 and 6 (i.e., roof), infills and stairs.

\begin{tabular}{ccccc}
\hline Load type & $\begin{array}{c}\text { Story 1-5 } \\
{\left[\mathrm{KN} / \mathrm{m}^{2}\right]}\end{array}$ & $\begin{array}{c}\text { Story 6 } \\
{\left[\mathrm{KN} / \mathrm{m}^{2}\right]}\end{array}$ & $\begin{array}{c}\text { Infills } \\
{[\mathrm{KN} / \mathrm{m}]}\end{array}$ & $\begin{array}{c}\text { Stairs } \\
{\left[\mathrm{KN} / \mathrm{m}^{2}\right]}\end{array}$ \\
\hline $\mathrm{G}$ & 6.4 & 6.1 & 5.5 & 5.3 \\
\hline $\mathrm{Q}$ & 2 & 1 & - & 4 \\
\hline \multicolumn{6}{c}{ Table 3. Assumed design loads. }
\end{tabular}

The material properties for the concrete and the steel reinforcement are assumed based on the codes provision and are listed in Table 4 and Table 5, respectively. 


\begin{tabular}{cccccc}
\hline \multicolumn{6}{c}{ Concrete } \\
\hline \multicolumn{3}{c}{ Building A } & \multicolumn{3}{c}{ Building B } \\
\hline $\mathrm{R}^{\prime}{ }_{\mathrm{bk}}$ & 250 & {$\left[\mathrm{~kg} / \mathrm{cm}^{2}\right]$} & $\mathrm{R}^{\prime}{ }_{\mathrm{bk}}$ & 250 & {$\left[\mathrm{~kg} / \mathrm{cm}^{2}\right]$} \\
\hline$\sigma_{\mathrm{c}}$ & 77.8 & {$\left[\mathrm{~kg} / \mathrm{cm}^{2}\right]$} & $\sigma_{\mathrm{c}}$ & 85 & {$\left[\mathrm{~kg} / \mathrm{cm}^{2}\right]$} \\
\hline$\tau_{\mathrm{b} 0}$ & 4 & {$\left[\mathrm{~kg} / \mathrm{cm}^{2}\right]$} & $\tau_{\mathrm{b} 0}$ & 5.3 & {$\left[\mathrm{~kg} / \mathrm{cm}^{2}\right]$} \\
\hline$\tau_{\mathrm{b} 1}$ & 14 & {$\left[\mathrm{~kg} / \mathrm{cm}^{2}\right]$} & $\tau_{\mathrm{b} 1}$ & 16.9 & {$\left[\mathrm{~kg} / \mathrm{cm}^{2}\right]$} \\
\hline
\end{tabular}

Table 4. Assumed material properties for concrete.

\begin{tabular}{|c|c|c|c|c|c|}
\hline Building & \multicolumn{5}{|c|}{ Steel Reinforcement } \\
\hline \multirow{2}{*}{ A } & \multicolumn{2}{|c|}{ Longitudinal (carbon) } & \multicolumn{3}{|c|}{ Transversal (mild) } \\
\hline & $\sigma_{\mathrm{y}}\left[\mathrm{kg} / \mathrm{cm}^{2}\right]$ & 2000 & $\sigma_{\mathrm{y}}$ & {$\left[\mathrm{kg} / \mathrm{cm}^{2}\right]$} & 1400 \\
\hline \multirow{2}{*}{ B } & \multicolumn{2}{|c|}{ Longitudinal (FeB44K) } & \multicolumn{3}{|c|}{ Transversal (FeB32K) } \\
\hline & $\sigma_{\mathrm{y}}\left[\mathrm{kg} / \mathrm{cm}^{2}\right]$ & 2600 & $\sigma_{\mathrm{y}}$ & {$\left[\mathrm{kg} / \mathrm{cm}^{2}\right]$} & 1600 \\
\hline
\end{tabular}

Table 5. Assumed material properties for steel reinforcement.

$\mathrm{R}$ 'bk, $\sigma_{\mathrm{c}}, \tau_{\mathrm{b} 0}$, and $\tau_{\mathrm{b} 0}$ are the concrete compressive strength, permissible stress, and shear strength without/with reinforcement, respectively. $\sigma_{y}$ is the steel permissible stress at the yielding of longitudinal and transversal reinforcement. Mild and carbon steel are associated to carbon percentages of $0.15-0.25 \%$ and $0.4-0.6 \%$, respectively.

\section{2 $\quad$ Finite element modeling}

The vulnerability analysis of Building A and B is performed through a Finite Element Method (FEM) approach. The FEM modeling has been performed in OpenSees [17] using the pre/post processor STKO [18], as shown in Figure 3.
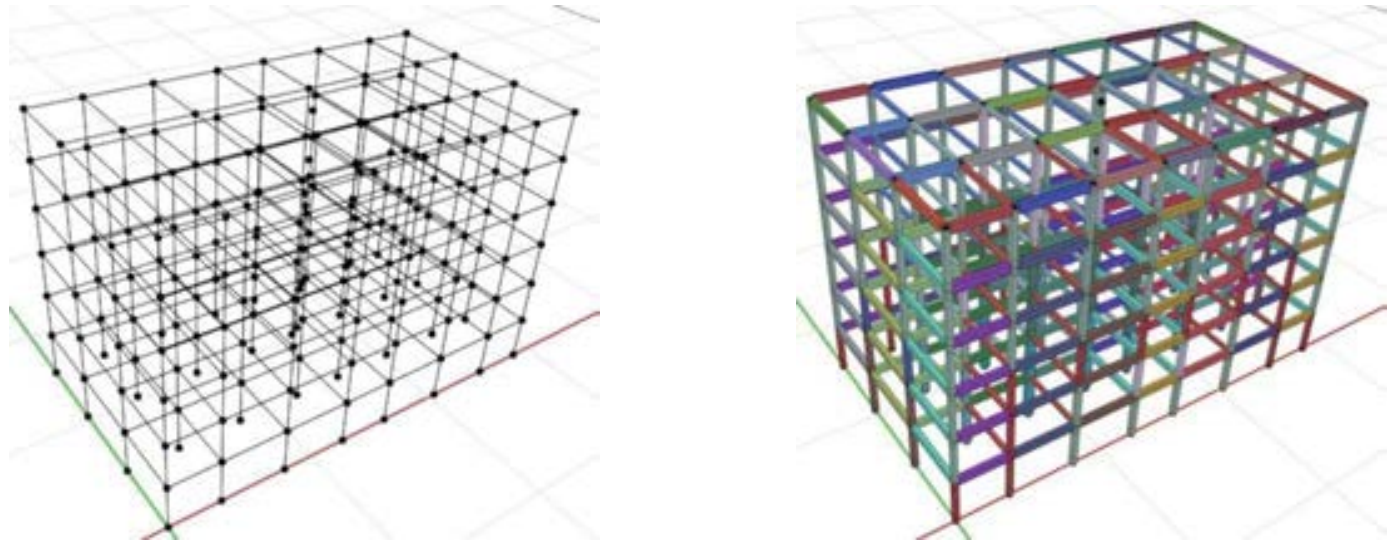

Figure 3. Graphical user interface of STKO.

Beams have been modeled as lumped plasticity elements combining a section based on socalled "phenomenological" laws and two plastic hinges of finite length at both ends with fiber section $[19,20]$. By combining these sections, it is possible to reduce the model complexity while describing its behavior with high accuracy [21]. Assumed phenomenological laws are different between the two buildings as they are based on the rebars type. Building A adopts smooth rebars, therefore the phenomenological law proposed by Verderame et al. (2018) [22] is assumed. On the other hand, Building B adopts corrugated bars, therefore the phenomenological law based on the Ibarra et al. (2005) [23] model with Haselton et al. (2008) [24] predictive equation is assumed. 
Columns have been modeled as fiber sections using the Concrete01 [25] and Steel02 [26] model for the RC and steel, respectively. The length of plastic hinges at both ends has been determined based on modern code provisions [27].

To correctly evaluate the seismic behavior of existing buildings, different material properties than those listed in Table 4 and Table 5 are assumed, in order to consider the aging effect. For the RC compressive strength, $f_{c}$, mean values provided by Masi et al. (2014) [28] have been used, which derived from a large scale in situ survey. For the steel yielding strength, $f_{y}$, values provided by the open-access software Stil (http://www.reluis.it/index.php?option=com content\&view=arti-cle\&id=199\&Itemid=136\&lang=it) have been used [29]. In addition, the elastic modulus, $E_{S}$, of Building A has been modified to consider the bond-slip that may occur with smooth bars. Assumed values for the structural modeling are listed in Table 6.

\begin{tabular}{cccccccccc}
\hline Building & \multicolumn{3}{c}{ Concrete } & \multicolumn{7}{c}{ Steel } \\
\hline A & $f_{c}$ & 18 & {$[\mathrm{MPa}]$} & $f_{y}$ & 350 & {$[\mathrm{MPa}]$} & $E_{s}$ & 175000 & {$[\mathrm{MPa}]$} \\
\hline B & $f_{c}$ & 20 & {$[\mathrm{MPa}]$} & $f_{y}$ & 470 & {$[\mathrm{MPa}]$} & $E_{s}$ & 206000 & {$[\mathrm{MPa}]$} \\
\hline
\end{tabular}

Table 6. Assumed values for the concrete and steel in the structural modeling.

Infills and stairs have not been modelled but have been considered only as loads.

\section{VULNERABILITY ANALYSIS}

\subsection{Seismic input}

The ground motions selection is crucial when performing NLDAs as they must be representative of the seismic hazard in the area under assessment [30] and the number must be sufficient to capture all possible damage states. In this paper, the ground motion selection proposed by Paolucci et al. (2020) [31] has been used. This selection includes 125 unscaled input motions have been determined for soil category A (rock) using the L'Aquila hazard spectra (Abruzzo Region, close to the Pescara Province) as target.

\subsection{Engineering Demand Parameter and Damage states}

The maximum insterstory drift ratio (IDR) in both horizontal directions is assumed as Engineering Demand Parameter (EDP) to determine the building's damage. Damage is classified according to the European Macroseismic Scale EMS-98 [32] and varies from D0 (no damage) to D5 (destruction or complete collapse). IDR values are associated to EMS-98 damage states by using the ranges proposed by Masi et al. $(2015,2021)[33,34]$ for medium and high-rise $(\geq$ 3 stories) GLD RC buildings, that are listed in Table 7.

\begin{tabular}{lc}
\hline Damage State & IDR $(\%)$ \\
\hline D0 (none) & $<0.1$ \\
\hline D1 (slight) & $0.1-0.25$ \\
\hline D2 (moderate) & $0.25-0.5$ \\
\hline D3 (substantial to heavy) & $0.5-1.0$ \\
\hline D4 (very heavy) & $1.0-2.5$ \\
\hline D5 (destruction) & $>2.5$ \\
\hline
\end{tabular}

Table 7. Assumed relationships between IDR values and EMS-98 damage states. 


\subsection{Fragility curves definition}

Selected ground motions have been applied on both horizontal directions thus obtaining 250 PGA-IDR values, which relate the maximum Peak Ground Acceleration of the considered ground motion to the maximum IDR among all story levels. Then, fragility curves are derived using the formulation proposed by FEMA 2018 [35], see Eq. 2.

$$
P(D k \mid P G A)=\Phi\left[\frac{1}{\beta_{D, D k}} \cdot \ln \left(\frac{P G A}{\overline{P G A}_{D k}}\right)\right] \quad k=1, \ldots, 5
$$

where $P(D k \mid P G A)$ is the probability of exceeding the $k$-th damage state, $D k$, given a PGA value, $\Phi$ is the Gaussian cumulative distribution function, $\beta_{D, D k}$ and $\overline{P G A}_{D k}$ are the logarithmic standard deviation and median value, respectively.

Obtained fragility curves for Building A and B are shown in Figure 4. As previously mentioned, 4 and 5 -story buildings have been derived by the 6 -story by taking the four and five upper stories, respectively.
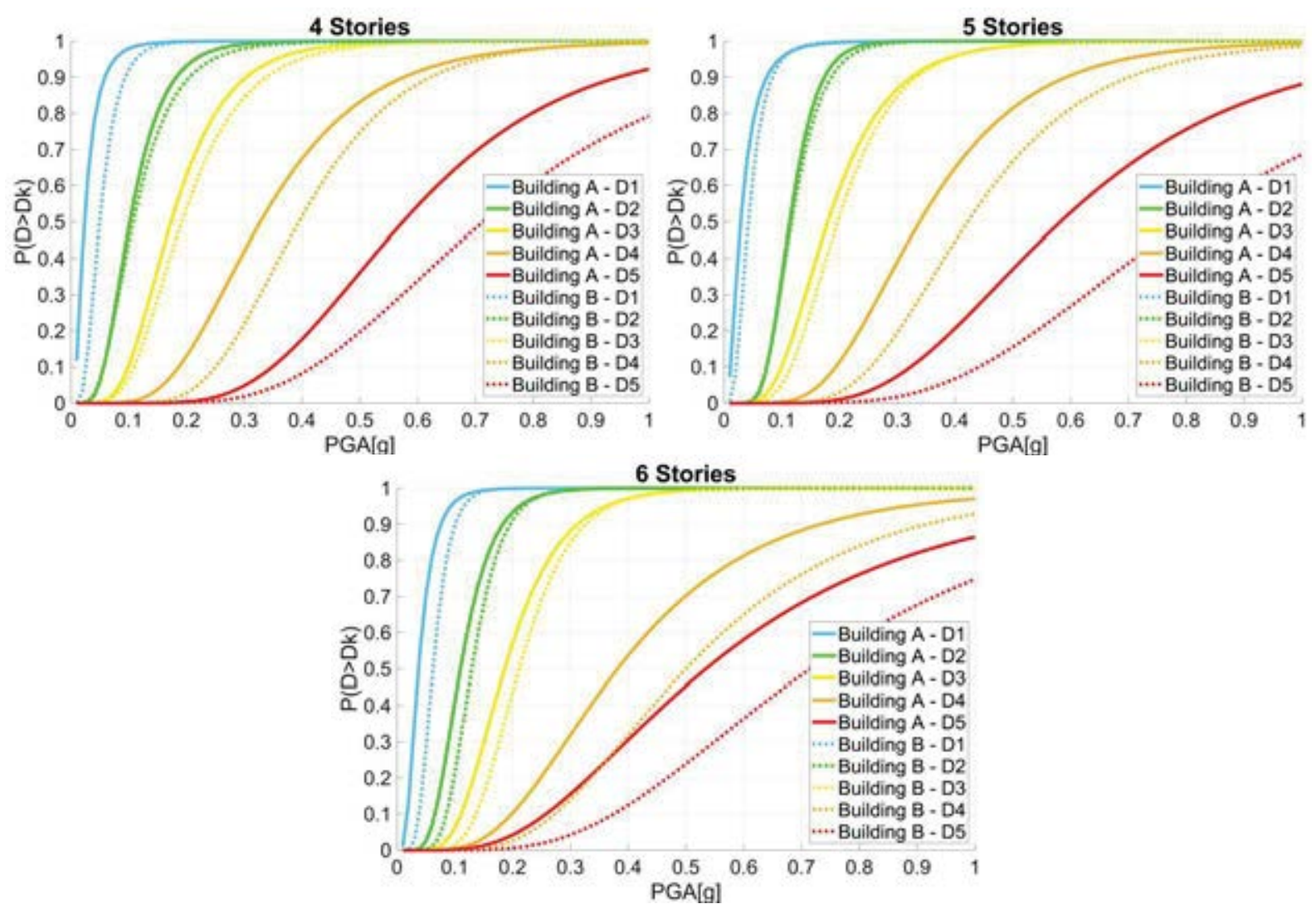

Figure 4. (clockwise) Fragility curves for 4-story, 5-story and 6-story Building A (designed with R.D.L. 1939) and Building B (designed according to D.M. '72).

Observing the graph, it is possible to note that fragility curves of the 4 and 5-story buildings do not significantly differ, while the 6-story buildings is significantly less vulnerable. This is possibly due to the fact that 4-story and 5-story buildings are both considered as "medium-rise", while the 6-story building is included in the "high-rise" category [36]. Then, Building B is consistently less vulnerable then Building A, thus noting how the evolution of codes is associated to an increase in the seismic performance. 


\section{SUMMARY AND CONCLUSIONS}

This paper has presented the vulnerability analysis of two RC building typologies that are representative of the built environment in the Pescara Province, Central Italy. Main characteristics of the typologies have been derived by an existing database of Italian residential buildings. Then, buildings have been modeled through a simulated design approach, also considering the aging effects.

A suite of ground motion records has been used to perform NLDAs whose outputs were used to derive fragility curves for five damage states. Obtained fragility curves show mediumrise buildings have a higher fragility than high rise ones. Finally, the evolution of the building code is associated to an increase in the seismic performance.

\section{ACKNOWLEDGMENTS}

The Authors wish to acknowledge M.Sc. students Michael Palmucci and Matteo Di Simone whose dissertation is part of the project.

\section{REFERENCES}

[1] C. Corbane, U. Hancilar, D. Ehrlich, T. De Groeve, Pan-European seismic risk assessment: a proof of concept using the Earthquake Loss Estimation Routine (ELER). Bull Earthq Eng, 15:1057-83, 2017.

[2] ICPD, National risk assessment, Overview of the potential major disasters in Italy: Seismic, volcanic, tsunami, hydro-geological/hydraulic and extreme weather, droughts and forest fire risks. Italian Civil Protection Department Technical report, 2018.

[3] UNDRO, Natural Disasters and Vulnerability Analysis. Geneva, Switzerland, 1980.

[4] P. Lin, N. Wang, Building portfolio fragility functions to support scalable community resilience assessment. Sustain Resilient Infrastruct, 1:108-22, 2016. https://doi.org/10.1080/23789689.2016.1254997.

[5] M. Mehrdad, A. Navid, M. Hassan, M. Hussam, J.W. van de Lindt, S.F. Pilkington, M.R. Ameri, Minimal Building Fragility Portfolio for Damage Assessment of Communities Subjected to Tornadoes. J Struct Eng, 144:4018072, 2018.

[6] O.M. Nofal, J.W. van de Lindt, Minimal Building Flood Fragility and Loss Function Portfolio for Resilience Analysis at the Community Level. Water, 12:2277, 2020.

[7] K. Porter, A Beginner's Guide to Fragility, Vulnerability, and Risk. Encycl Earth. Eng, Springer, 2015.

[8] G.M. Verderame, M. Polese, C. Mariniello, G. Manfredi, A simulated design procedure for the assessment of seismic capacity of existing reinforced concrete buildings. $A d v$ Eng Softw, 41:323-35, 2010.

[9] T. Rossetto, N. Peiris, J. Alarcon, E. So, S. Sargeant, V. Swords-Daniels, C. Libberton, E. Verrucci, D. Del Re, M. Free, The L'Aquila, Italy Earthquake of 6 April 2009: a field report by EEFIT. 2009.

[10] G. Fiorentino, A. Forte, E. Pagano, F. Sabetta, C. Baggio, D. Lavorato, C. Nuti, S. Santini, Damage patterns in the town of Amatrice after August 24th, 2016 Central Italy earthquakes. Bull Earthq Eng, 16:1399-423, 2018. 
[11] Presidenza del Consiglio dei Ministri, Primi elementi in materia di criteri generali per la classificazione sismica del territorio nazionale e di normative tecniche per le costruzioni in zona sismica. Italy: O.P.C.M. 3274 20/3/2003; 2003.

[12] ISTAT, Edifici residenziali $2011 . \quad \mathrm{http} / /$ daticensimentopopolazione.istat.it/Index.aspx?DataSetCode=DICA_EDIFICI1 (accessed September 14, 2020).

[13] G. Zuccaro, M. Dolce, D. De Gregorio, E. Speranza, C. Moroni, La scheda CARTIS per la caratterizzazione tipologico-strutturale dei comparti urbani costituiti da edifici ordinari. Valutazione dell'esposizione in analisi di rischio sismico. $34^{\text {th }}$ national conference of GNGTS, Trieste, 2015.

[14] M. Bosco, G.A.F. Ferrara, A. Ghersi, E.M. Marino, P.P. Rossi, Predicting displacement demand of multi-storey asymmetric buildings by nonlinear static analysis and corrective eccentricities. Eng Struct, 99:373-87, 2015.

[15] M. Bosco, A. Ghersi, E.M. Marino, P.P. Rossi, Generalized corrective eccentricities for nonlinear static analysis of buildings with framed or braced structure. Bull Earthq Eng, 15:4887-913, 2017.

[16] Consiglio Nazionale delle Ricerche and Ente nazionale italiano di unificazione, Ipotesi di carico sulle costruzioni. Italy: CNR UNI 10012:67, 1967.

[17] F. McKenna, G.L. Fenves, M.H. Scott, Open system for earthquake engineering simulation. Univ California, Berkeley, CA, 2000.

[18] M. Petracca, F. Candeloro, G. Camata, STKO user manual. ASDEA Softw Technol, Pescara, 2017.

[19] E. Spacone, F.C. Filippou, F.F. Taucer, Fibre Beam-Column Model for Non-Linear Analysis of R/C Frames: Part I. Formulation. Earthq Eng Struct Dyn, 25:711-25, 1996.

[20] E. Spacone, F.C. Filippou, F.F. Taucer, Fibre Beam-Column Model for Non-Linear Analysis of R/C Frames: Part II. Applications. Earthq Eng Struct Dyn, 25:727-42, 1996.

[21] M. Terrenzi, E. Spacone, G. Camata, Comparison Between Phenomenological and Fiber-Section Non-linear Models. Front Built Environ, 6:38, 2020.

[22] G.M. Verderame, P. Ricci, An empirical approach for nonlinear modelling and deformation capacity assessment of RC columns with plain bars. Eng Struct, 176:539-54, 2018.

[23] L.F. Ibarra, R.A. Medina, H. Krawinkler, Hysteretic models that incorporate strength and stiffness deterioration. Earthq Eng Struct Dyn, 34:1489-511, 2005.

[24] C.B. Haselton, A.B. Liel, S. Taylor Lange, G.G. Deierlein, Beam-column element model calibrated for predicting flexural response leading to global collapse of RC frame buildings. PEER Report, 2008.

[25] K.D. Charles, P. Robert, Flexural Members with Confined Concrete. J Struct Div, 97:1969-90, 1971.

[26] M. Menegotto, P. Pinto, Method of analysis for cyclically loaded RC plane frames including changes in geometry and non-elastic behavior of elements under combined normal force and bending. Proceedings of IABSE Symposium on Resistance and Ulti- 
mate Deform ability of Structures Acted on by Well Defined Repeated Loads, 11:15-22, 1973.

[27] Consiglio Superiore dei Lavori Pubblici, Istruzioni per l'applicazione dell'aggiornamento delle "Norme tecniche per le costruzioni" di cui al decreto ministeriale 17 gennaio 2018, 2019.

[28] A. Masi, A. Digrisolo, G. Santarsiero, Concrete Strength Variability in Italian RC Buildings: Analysis of a Large DataBase of Core Tests. Appl Mech Mater, 597:283-90, 2014

[29] G.M. Verderame, P. Ricci, M. Esposito, F.C. Sansiviero, Le Caratteristiche Meccaniche degli Acciai Impiegati nelle Strutture in ca realizzate dal 1950 al 1980. XXVI Convegno Nazionale di Geotecnica AICAP, Padova, 2011.

[30] P. Bazzurro, C.A. Cornell, Seismic Hazard Analysis of Nonlinear Structures. I: Methodology. J Struct Eng, 120:3320-44, 1994.

[31] R. Paolucci, A.G. Ozcebe, C. Smerzini, A. Masi, V. Manfredi, Selection and spectral matching of recorded ground motions for earthquake engineering analysis 2020. https://143.225.144.186:5001/ (accessed March 19, 2021).

[32] G, Grünthal, European macroseismic scale 1998. Cahiers du Centre Européen de Géodynamique et de Séismologie, 1998.

[33] A. Masi, A. Digrisolo, V. Manfredi, Fragility curves of gravity-load designed RC buildings with regularity in plan. Earthquakes Struct, 9:1-27, 2015.

[34] A. Masi, S. Lagomarsino, M. Dolce, V. Manfredi, D. Ottonelli, Towards the updated Italian seismic risk assessment: exposure and vulnerability modelling. Bull Earthq Eng, 2021.

[35] FEMA P-58-1, Seismic Performance Assessment of Buildings, Volume 1-Methodology. Applied Technology Council, Redwood City, California, 2018.

[36] FEMA. Hazus 4.2 SP3 Earthquake Model - Technical Manual, 2020. 